\title{
Islamic Law as A Value to Solve The Humanitarian Crisis: Lessons from Indonesia
}

\author{
Sholahuddin Al-Fatih ${ }^{1}$, Nur Putri Hidayah ${ }^{2}$, Isdian Anggraeny ${ }^{3}$ \\ \{sholahuddin.alfath@gmail.com ${ }^{1}$, nurputri88@gmail.com ${ }^{2}$, isdian@umm.ac.id\} \\ ${ }^{123}$ Faculty of Law, University of Muhammadiyah Malang \\ Jl. Raya Tlogomas No. 246 Malang, East Java, Indonesia
}

\begin{abstract}
This research aims to discuss about the humanitarian crisis that occurring in Indonesia. Nowadays, humanitarian crisis in Indonesia is due to the lack of fulfillment of human rights, intolerance, racism and other factors. The humanitarian crisis should not happen, if Indonesia applied the principle of Islamic Law, named Maqashid Sharia. Implementation of the concept of Maqashid Sharia should be carried out with the approach of the Qur'an and Hadith. Based on literature studies, this research will analyze how to Indonesian Government solve their humanitarian crisis problem by using Maqashid Sharia in practice. In the end, the author found that the humanitarian crisis in Indonesia could be prevent by Maqashid Sharia.
\end{abstract}

Keywords: Islamic Law, Value, Maqashid Sharia, Humanitarian Crisis

\section{Introduction}

Historically, democracy has emerged and developed long ago. Since it was first discovered, the terms and conceptions of democracy have metamorphosed several times. This situation eventually forced democratic countries to implement democratic systems with different models and characters. However, the majority of justices in several countries are very strongly influenced by the values or culture of the nation and its historical side, including Indonesia. The source of democracy in this country consists of 3 (three). One socialism from the west which defends the principles and values of humanity, this is also believed to be a goal. Second, Islamic values that command to do right and reflect God's justice in the life of society, nation, and state. Three, the way of life of collectivism or harmony in togetherness as in villages in Indonesia. These three sources of democracy can guarantee the sustainability of democracy that grows and develops in Indonesia so that democracy in Indonesia has a strong and deeply rooted basis [1].

Democracy has many meanings and interpretations. The meaning and interpretation are closely related to the social system that supports and follows it. Democracy contains elements and universal values (common denominator) as well as contextual contents attached to a particular social system (cultural relativism) [1]. So that almost certainly in every democratic country, there is a value and local wisdom that becomes its supporting style.

According to language, democracy consists of two words derived from Greek, namely demos, which means people and cratein or kratos, which means power or sovereignty. In the language of demo-cratein or demo-kratos (democracy) is the state of the state wherein the system of government sovereignty is in the hands of the people, the people in power, people's 
government, and power by the people [2]. In other words, in a democratic country, the people are the highest authority.

The legal and political experts agree that the term democracy comes from the era of the city-state (polis) in the Ancient Greek period. However, it is believed that the model of democracy in the modern era does not originate there. The assumptions and practices of democratic state administration at that time were very different from the practices and dynamics of democracy in the modern era now. In ancient Greece, democracy was not founded on the idea of individual citizens' rights. This right is only given to a small number of citizens who live in the city. The word democracy in the modern sense began to be used in the nineteenth century to designate a system of representative government, where the people's representatives were elected through free competitive elections by citizens [3].

Democracy will not come, grow, and develop by itself in the life of society, state, and nation. Therefore democracy requires the real effort of every citizen and supporting device that is conducive to culture as a manifestation of a community's mindset and design. The concrete form of the manifestation is made democracy as a way of life in every aspect of state life both by the people and the government. Democratic governance requires a democratic culture to make it exist and upright. The culture of democracy is in the community itself. A good government can grow and be stable if society, in general, has a positive and proactive attitude towards the basic norms of democracy. A truly democratic political system, the minimum requirement is the existence of a balanced political power of the community, besides the existence of other balance factors, such as ideology, economic, social, and cultural systems [4].

As for the norms that make the democratic way of life as follows [4]:

1. The importance of awareness of diversity and moderation;

2. Deliberation;

3. Moral considerations;

4. An honest and healthy agreement;

5. Fulfillment of economic aspects;

6. Collaboration between citizens and attitudes to trust each other's good intentions;

7. A democratic outlook on life must be an integral part of the education system [5].

If we interpret the true identity of a democratic state, then democratic ideas must be substantially realized in aspects of state life, both in the political, social, and economic fields. This is in accordance with the modern democratic political theory popularized by Boron, where the democratic model is divided into four levels, namely [6]:

1. Electoral Democracy;

2. Political Democracy;

3. Social Democracy;

4. Economic Democracy.

From these four levels, to achieve a true concept of the rule of law and democracy, there are several pre-conditions that must be met. The prerequisite is seen from the way to interpret the concept of the rule of law and democracy. Democracy can be explained in two aspects. First, democracy as a system, then democracy is bound by the rules of the game (constitution, laws, regulations) that have been mutually agreed upon. Second, democracy as an ideology. Here is explained how to realize government by a concern of The people based on an ideology. Here the importance of democratic countries respecting the values of human rights, namely freedom of thought and expression, freedom of the press, organization, freedom of speech, freedom of choice of representatives, freedom of politics, freedom of religion, and so on [4].

A scholar, Ruslan, emphasizes the concept of democracy to the fulfilment of human rights that will guarantee openness in living systems of society, nation, and state [4]. However, lately, 
we often get information that some community groups, especially in Indonesia, are starting to be anti-democratic. They allegedly want to replace the Pancasila ideology and democratic values with other ideologies, such as the Khilafah, which is actually taught in the teachings of Islam. So, the question arises, how true is the Islamic law to see democracy and the values of humanism contained in it. Is Islam really anti-democracy or just the opposite.

\section{Method}

This research is a type of legal research, namely research conducted to produce new arguments, theories, or concepts as a prescription in solving the problems faced [7]. Meanwhile, the research approach used is the conceptual approach and the statue approach. This research uses primary and secondary legal materials. Primary legal material consists of statutory provisions and case to be studied. Whereas secondary legal material consists of textbooks, legal dictionaries, and legal journals.

\section{Result and Discussion}

\subsection{Democracy in Indonesia on Islamic Law View}

Fundamentally, the theory of democracy is a government that places sovereignty in the hands of the people. Leaders who are appointed in a democratic system are bound by social contracts to carry out people's aspirations. The existence of criticism, correction, and even the dismissal of leaders in the democratic system, are all related to the aspirations of the people. Parmudi argues that democracy is a system of government in a country where all citizens have rights, obligations, positions and powers both in carrying out their lives and in participating in state power, where the people have the right to participate in running the country or oversee the running of state power, both directly for example through public spaces (public spaces) and through representatives who have been chosen fairly and honestly [8].

According to Ma'arif, basically, Islam recognizes the existence of democracy [9]. Democracy taught by Islam was born first and is clearer than democracy originating from the West (Ancient Greece). Islam not only supports but can make the principles of teachings in social life [10]. It can be understood that what is meant is the democracy that is compatible with Islam. Whereas in the view of Fachrudin, democracy, in accordance with Islam, contains democratic ideas and institutions based on the following principles or values: First, the highest and absolute power belongs to God. Shura is the basis of the principle of God's sovereignty and sharia supremacy. Second, the highest and most regal authority in an Islamic state is the Holy Qur'an and the Sunnah, while human power is under God's control. Third, humans on earth derive their power from God's power according to the concept of the Caliphate [11].

In any concept of shura, the issues to be discussed in the shura council must first be referred to the basis and source of the law of the Koran and Sunnah, and if there is no strong text (the basis of the Koran and Sunnah), then the members of the shura assembly do ijtihad to seek law by comparing and examining common verses and traditions as well as adjusting and considering the case being discussed then it is violated with the existing law that is adjacent to the case under discussion. In the Shura system, the truth is not known by the majority, but by its compatibility with the source of Sharia law. Whereas in a democratic system, truth is the majority vote despite opposing the clear Shari'a of God. In addition, he also said that shura is a form of faith because with shura we practice the teachings of Islam [12]. While democracy is a form of kufr to God, because if the majority decides the disbelief, then that is the decision that must be followed 
according to them, likewise, if the Shura respects the scholars, while democracy respects the infidels.

According to Abdul Qadir Audah mentioned by A. Hasymy that there are five rules that form the principle of shura, summarized as follows [13]:

1. Shura rights set for the government and the people in this case both parties are equal, not there is one party that has more rights than another. Just as the leaders of a country may at any time state their opinions in government affairs, so can the people or the people's representatives.

2. The obligation of the government to deliberate with the people in state affairs, both large and small. And the people can exercise their rights at any time to give advice to the government or propose regulations and can sue the government to implement Islamic sharia.

3. Shura is based on sincere lillahi; the ideals of shura must be carried out sincerely because God is to uphold the truth of Islam, without being influenced by inheritance and personal interests, nor by the interests of groups and regions.

4. Shura is not unanimous; it does not become a necessity so that all people (people's representatives) agree on one opinion. Decisions are the opinions of the people; after exchanging thoughts freely, without any pressure.

5. The necessity of implementing decisions by a small group. After deliberation freely, all groups must carry out the decision, especially by the small groups who are defeated. Regarding this, the Prophet gave an example in the Uhud war negotiations, where the Apostle submitted to the will of the people who wanted to meet the enemy to the hill of Uhud, while the prophet himself thought it was better to stay in Medina. After becoming the decision with the most votes, the Apostle immediately put on his armor and went out to lead the crowd towards the battlefield.

Islam also limits the power and authority of rulers. This ethical value is outlined by Rasulullah SAW; "Obey the leader as long as he does not command evil." This hadith ipso facto gives political restrictions in relation to the problem of limiting the position of leader. That is if power has opened up, given space for, or ordered to despotism, then the community is obliged to boost and overthrow that power. In the Koran, this type of leader is depicted with the symbolization of thâghût (tyranny) followed by the derivation of "'aduw" (repeated 99 times), "thagâ" (repeated 39 times), "Pharaoh" (repeated 74 times), "Baghâ" (repeated 97 times). The symbolization of "thaghût" along with its derivation, according to Mohamed Arkoun, contains the effectiveness of ethical values, which was later able to inspire the Islamic revolution in Iran in 1979 [14].

The limitation of power and authority of these rulers was stated by Syed Hussein Alatas as quoted by Ismail, as one of the democratic norms highlighted in sharia [15]. A rule states that "political power must be exercised within the framework of the Shari'a" (Sharia is the highest law of the Muslim community). This means that the authorities must submit themselves to the laws, values, and principles of religion.

According to Islamil, restrictions on state authority can also be aligned with other democratic principles, namely the principle of public responsibility [16]. Leaders must be accountable to the people not only in terms of general administration but also in terms of how public funds are managed. Even a caliph himself must obtain public approval before they can use public money for a personal purpose. The principle of public responsibility (public uncountability) is supported in the Koran. "... their business is (decided) with deliberation between them." This verse points to a clear concept of deliberation (with the people) regarding matters relating to the public interest. This is the basis of administrative relations between the 
government and the people. Therefore according to this principle of public responsibility, the people have the right to choose and dismiss their rulers.

Previously it was agreed that Islamic teachings contained democratic values. Democracy itself can be in the form of institutions and value systems. In other words, democracy is a concept of a political system. Based on this, Islam should favour the concept of a political system or the concept of a democratic state. Because, after the democratic value system is "Islamized," the political system preferences that were initially empty become contained. Islam and democracy complement each other. Islam fills value preferences, while democracy provides the concept/form of the political system. Thus, democratization is not impossible in countries with a majority Muslim population. In other words, the Islamic religion is able to contribute to the process of democratization as long as it is held that Islam is always trying to "liberate."

According to Sudirman, as quoted by Ichsan, the most fundamental difference between the concept of shura according to Islam and democracy according to the West is that deliberation according to Islam is a system of government in which all people participate in governing through ulil amri and all affairs must be returned to the basis and source the law that was revealed by Allah SWT and was exemplified by Rasulullah SAW [17]. Democracy is a system of government in which all people participate in governing both through direct means such as referendums and indirectly through the mediation of their representatives.

So the concept of shura, according to Islam, is a government system where Allah SWT is sovereign, while the concept of democracy is a government system where people are sovereign. Therefore the concept of shura according to Islam and the concept of democracy, according to the West (Greek) is very much different. Shura bases that all problems must be returned to the Koran and Sunnah, while democracy will return all problems to the people. In shura, rules, laws, laws must first be referred to the basis and source of the law of Allah SWT and the Sunnah of Rasulullah SAW, while in democracy, rules, laws, laws continue to be built, formed, determined based on what is generated by thought the people either directly like the referendum or through their representatives.

\subsection{Islamic Law Values (accompanying Democracy) to Solve Humanitarian Crisis}

According to Fachrudin (2006), democracy following Islam contains democratic ideas and institutions based on Islamic principles or values where the supreme power is only in God, and shura is the basic principle of the sovereignty of God and Sharia supremacy [11]. That is, in a country that embraces democracy in Islam, it is not justified in having an authoritarian and ruling leader for life as is happening today in Muslim countries.

Furthermore, Muslim countries must start a revolution and amend their constitution to be in harmony with the Qur'an. State leaders must be limited by the highest law, both the Qur'an and the constitution, while the administration of government must be based on Sharia and/or the constitution. Islam basically provides basic principles and values in managing an organization or government. Al-Qur'an and As-sunnah, in this issue, have hinted at some basic principles and values relating to leadership, community life, organization, state (read: politics), including a government system in which the notes are social contracts. The principles or values include the principle of monotheism, As-syura (deliberation) Al-is (fair) Hurriyah Ma'a Mas'uliyyah (freedom with responsibility) Legal Certainty, Guaranteed Haq ul Ibad (Human Rights) and etc.

Islamic law is intended for the benefit of living in the world and the hereafter. And the scope of Islamic law covers the area of religion and country. Islamic shariah generally applies to all humanity and is eternal until the Day of Judgment. The laws strengthen and strengthen each other, both in the fields of creed, worship, ethics, and muamalah, in order to realize the 
peak of the pleasure of Allah SWT, peace of life, faith, happiness, comfort and regularity of life and even give happiness to the world as a whole. All that is done through conscious awareness, sense of responsibility for obligations, feelings are always monitored by Allah SWT in all aspects of life, both when alone or in front of others, and by glorifying the rights of others.

Through democracy that guarantees the fulfilment of human rights and the values of humanism, modern Islamic countries continue to fight for the codification of humanism values in accordance with the provisions of Islamic law in various conferences, both through the United Nations, the OIC and so on. Although there have been efforts from Muslim countries to support the fulfilment of human rights, in reality, there are still many countries that have not been serious about complying with the declaration. One form of state obedience is in the form of ratification. Ratification is mostly one way of ratifying an international treaty to be able to become one of the legal products in the countries participating in the agreement - the term ratification used in the practice of international treaty law. The ratification of international treaties can be done in the form of legislation or in the form of a constitution. Based on the provisions of Article 2 paragraph (1) b of the 1969 Vienna Convention on International Treaties, ratifications are: "Ratification," "acceptance," "approval," and "accession" mean in each case the international act so named when a State establishes on the international plane its consent to be bound by a teary.

History has proven that the inclusion of democratic principles and the values of humanism based on Islamic law in the constitution has brought peace and prosperity to the country and its people. This is as done by the Arab kingdom, which included the principles of democracy and the fulfilment of human rights in the Charter of Medina. The core of the Medina charter contains the principles of equality, brotherhood, unity, freedom, religious tolerance, peace, justice, please help, and defend the persecuted. While the substance of the summary of the Medina Charter, as summarized by Sudjana includes [18]:

1. Monotheism, namely, recognizing the existence of one god (Articles 22, 23, 42, and the final part of Article 42).

2. Unity and integrity (Articles 1, 15, 17, 25, and 27). In these Articles, it is stated that the entire population of Medina is one person. There is only one protection if Jews have followed this charter, it means they are entitled to security and religious protection.

3. Equality and justice (Articles 1, 12, 15, 16, 19, 22, 23, 24, 37 and 40). These articles contain the principle that all residents of Medina have the same status before the law and must enforce the law and justice.

4. Freedom of religion (Article 25). Jews are free to practice their religion, and Muslims are also free to practice Islamic law.

5. Defend the country (Articles 24, 37, 38, and 44). This article explains that every citizen of Medina who recognizes the Medina charter has the same obligation to uphold and defend Medina from enemy attacks, both attacks from outside and from within.

6. Recognition and preservation of customs (Articles 2 to 10). These articles state that good practices among Jews must be recognized and preserved.

7. The supremacy of Islamic law (Articles 23 and 24). Every dispute must be resolved according to the provisions of Allah and the provisions of the Prophet Muhammad (AlQuran and Sunna)

8. The politics of peace and internal protection and the problem of external peace (Articles 15, 17, 36, 37, 39, 40, 41, 47). 


\section{Conclusion}

Islamic law has a view of the concept of democracy, which is based on the values contained in the Qur'an and Hadith. If, according to democracy, the highest sovereignty is in the hands of the people, then according to Islam, the highest sovereignty is absolutely God's. The Shura Council aims to find solutions based on provisions in the Qur'an and Hadith, not to take a majority vote based on general agreements as is usual in democracy. Islam then gives color in modern democracies with the limits of power for rulers so that there is no arbitrary action (abuse of power). Therefore, in today's modern democracy, Islam is present to fill preference values, while democracy itself provides the concept/form of the political system.

In Islam, there are the principles of Maqashid Sharia or ad-dloluriyat al-khomsah or alhuquq al-insaniyah Fi al-Islam, which are five basic things that must be maintained by each individual, including hifdzu al-din (respect for religious freedom), hifdzu al-mal (mal. respect for property), hifdzu al-nafs Kwa al-'ird (respect for the soul, the right to life and individual honor), hifz al-aql (respect for freedom of thought), and hifz al-nasl (a necessity for protecting offspring). Those values, will help society to solve their humanitarian crisis, especially in Indonesia.

\section{References}

[1] M. Hatta, Menuju Negara Hukum. Jakarta: Idayu Press, 1977.

[2] M. Mochtar, "Demokrasi dan Hak Asasi Manusia." 2005.

[3] J. Gaffar and R. Budiarti, Politik Hukum Pemilu. Jakarta: KONPress, 2012.

[4] I. Hidayat, Teori-Teori Politik. Malang: Setara Press, 2012.

[5] Z. F. Aditya and S. Al-Fatih, "Democracy and Human Rights As A Solution To Resolve The Humanitarian Crisis In Muslim Countries," in Conference On Islamic Studies (ICIS), 2017.

[6] Soebagio, "Distorsi dalam Transisi Demokrasi di Indonesia," J. Makara, vol. 13, no. 2, pp. 111-116, 2009.

[7] Peter Mahmud Marzuki, Penelitian Hukum. Jakarta: Kencana Prenada Media Group, 2013.

[8] M. Parmudi, "ISLAM DAN DEMOKRASI DI INDONESIA: Dalam Perspektif Pengembangan Pemikiran Politik Islam," Semarang, 2014.

[9] A. Ma'arif, Islam dan Politik: Teori Belah Bambu Masa Demokrasi Terpimpin (19591965). Jakarta: Gema Insani, 1996.

[10] F. Aulia and S. Al-Fatih, "Perbandingan Sistem Hukum Common Law, Civil Law dan Islamic Law dalam Perspektif Sejarah dan Karakteristik Berpikir ," Leg. J. Ilm. Huk., vol. 25, no. 1, pp. 98-113, 2017.

[11] F. Fachruddin, Agama dan Pendidikan Demokrasi. Jakarta: Pustaka Alvabet, 2006.

[12] Haris and S. Al-Fatih, "School of Intuition as An Education for Child to Prevent Corruption in Indonesia," TEST Eng. Manag., vol. 83, pp. 11884-11892, Apr. 2020.

[13] A. Hasymy, Where is the Islamic State Located. Singapore: National Library, 1970.

[14] M. Arkoun, Al-Fikr Al-Islamiy: Qiraah Ilmiyyah. Beirut: Markaz alInma al-Qaumiy, 1996.

[15] S. Alatas, "Elements of Islamic Culture, Symposium On The Cultural Heritage of Singapore," 1975.

[16] F. Islamil and I. Islam, Ilahiyah dan Realitas Insaniyah. Yogyakarta: Tiara Wacana, 
2009.

[17] M. Ichsan, "Demokrasi dan Syura: Persepektif Islam dan Barat," Subst. J. Ilmu-Ilmu Ushuluddin, vol. 16, no. 1, pp. 1-12, Apr. 2014, doi: 10.22373/SUBTANTIA.V16I1.4913.

[18] E. Sudjana, HAM dalam Perspektif Islam. Jakarta: Nuansa Madani, 2002. 